\title{
Assessment of Groundwater Quality Around an Active Dumpsite using Pollution Index
}

\author{
Ogbaran $\mathrm{AN}^{1}$ and Uguru $\mathrm{H}^{2 *}$ \\ ${ }^{1}$ Department of Civil Engineering Technology, Delta State Polytechnic, Nigeria \\ ${ }^{2}$ Department of Agricultural and Bio-Environmental Engineering Technology, Delta State Polytechnic, Nigeria
}

Submission: March 03, 2021; Published: March 16, 2021

*Corresponding author: Uguru H, Department of Agricultural and Bio-Environmental Engineering Technology, Delta State Polytechnic, Nigeria

Abstract

Groundwater pollution had become a major concern to civil and environmental engineers, due to its threat to the ecosystems. This study was aimed to evaluate the impact of an active dumpsite on the groundwater of Ozoro Community of Delta State, Nigeria. Four groundwater samples (three borehole and one local hand dug wells) were collected from four different locations around an active dumpsite, during November 2020. Six heavy metals (iron, cadmium, copper, zinc, lead and nickel) of the water samples collected were tested according to ASTM International standards. Results obtained from the laboratory tests revealed that heavy metals concentrations, varied across the dumpsite vicinity; and were higher than the values obtained at the reference point. Irrespective of the sampled location, it was observed from the results that the copper, zinc and nickel concentrations in the groundwater generally met the WHO criteria for domestic water quality. The results of the contamination factor revealed the groundwater within the study area had high degree contamination of iron, cadmium and lead. In terms of the pollution load index, the results showed that the groundwater within the study area was highly polluted with $\mathrm{Fe}, \mathrm{Cd}, \mathrm{Zn}$ and $\mathrm{Ni}$; while the area was moderately pollution with $\mathrm{Cu}$. These results had revealed the relevance of constant monitoring of the groundwater quality around dumpsites within Delta State, in order to minimize the risk of water-borne diseases.

Keywords: Correlation analysis; Groundwater; Heavy metals; Pollution index; Water quality

\section{Introduction}

Groundwateris one of the mostimportantand abundant natural resources in the earth; as it is essential for the survival of plants and animals on the universe. Groundwater covers about $0.6 \%$ of the world total water resources [1]. Heavy metals contamination of the soil and water bodies has become a serious environmental problem, due to the persistence and non-biodegradable nature of these metals ions. This will lead to bio-accumulation of these heavy metals by plants and animals, which can lead to serious health problems along the food chain. The groundwater can be contaminated by these toxic heavy metals either through direct atmospheric deposition or geologic weathering or discharge of industrial waste materials into the environment [2]. The negative impacts of heavy metals on human beings cannot be over-emphasized. The Agency for Toxic Substances and Disease Registry (ATSDR) stated that the concentration of heavy metals on the human bodies, is dependent on the quantity ingested by the human being, the duration, exposure pattern, personal traits and habits, etc. $[3,4]$.
In Nigeria, solid wastes are usually deposited in lowlands without considering their impacts on the ecosystem; since it is considered as an easier and cheaper waste management option, compared to other options like incineration method [5]. Indiscriminate disposal of solid wastes had become a major problem in many urban and rural areas across Nigeria. This act had resulted to the contamination of the ground water with heavy metals and other harmful micro-organisms [6]. Ofomola et al. [7] investigated the impact of leachates from solid waste on the groundwater Ughelli community, Delta State, Nigeria; and they reported that the leachates produced by these solid wastes had negative impact on the groundwater quality, within the vicinity of the dumpsites. According to Al-Khaldi [8] and Akpomrere and Uguru [9], the pollution effect of solid wastes leachate on the environment is influenced by: the concentration of the leachate, the soil geotechnical properties, volume of the leachate discharged into the environment, aquifer depth, geochemical properties of the soil, total vegetation cover, etc. Likewise, Rafizul et al. [10] stated 


\section{Civil Engineering Research Journal}

that the age of the dumpsite, degree of compression, prevailing environmental conditions, and the dumpsite hydrological pattern; determine the formation and concentration of leachates from solid wastes in a dumpsite.

Although, several studies $[11,12]$ have been carried out on the effect of dumpsites on the ecosystem, yet there is no reported case on the impact of dumpsite on the groundwater quality of Ozoro community of Delta State. In this present study, groundwater samples were collected from the vicinity of an active dumpsite, at Ozoro community of Delta State, Nigeria. The main aim of the study was to determine the concentrations and distribution of heavy metals in the groundwater from the study area. The objectives of this present study were: (i) to determine the impact of the leachates from the solid wastes on the groundwater quality of the study area, (ii) to evaluate the heavy metals (iron "Fe", cadmium "Cd", copper "Cu", zinc "Zn", lead "Pb" and nickel "Ni") pollution level in the study area, using contamination factor (CF) and pollution load index (PLI)

\section{Materials and Methods}

\section{Study Area Description}
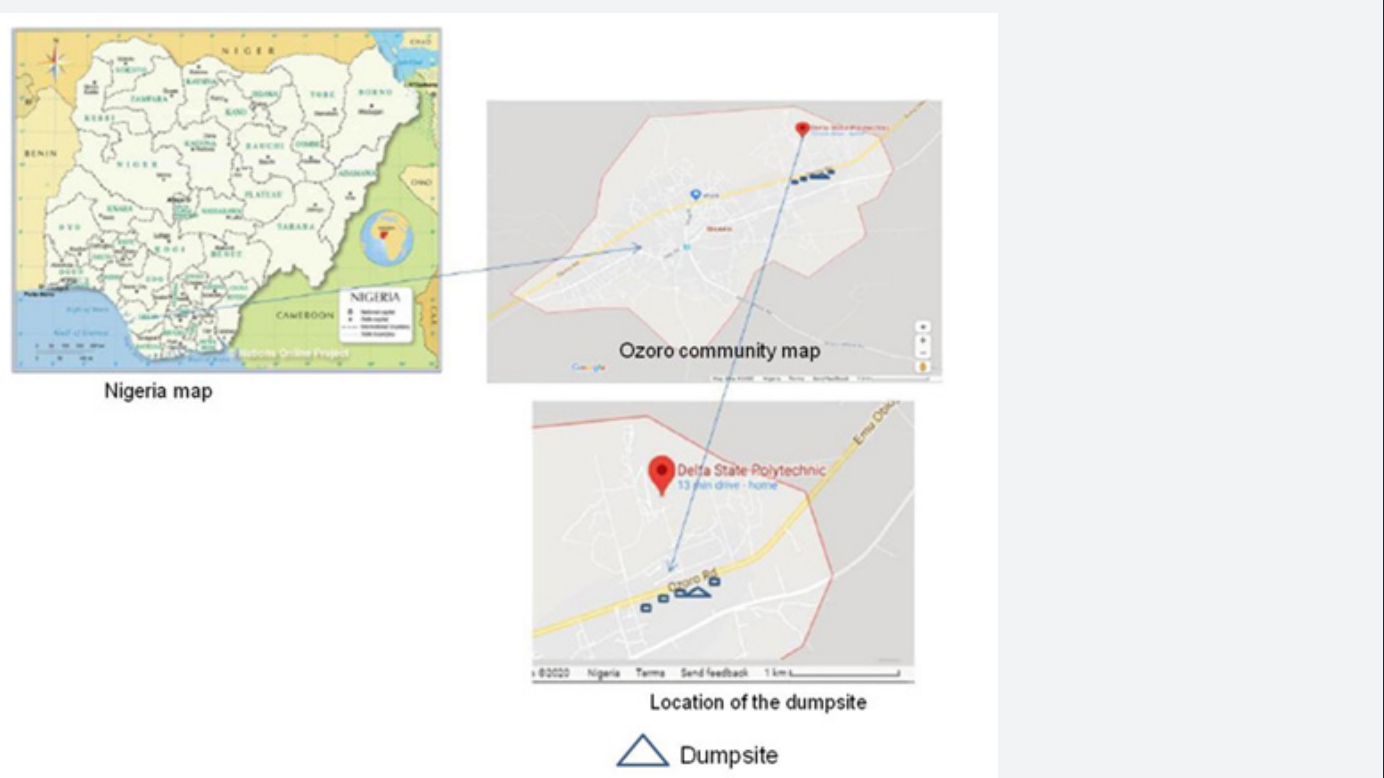

Figure 1: Map of Ozoro community, in Isoko north local government area of Delta state, Nigeria showing the dumpsite where the soil samples collected. Source: Google map [34].

The dumpsite is located at Ozoro community, Delta State, Nigeria. It is the only active dumpsite within the community, with geographical co-ordinates of latitude 5033'17" North, longitude 60 14'38'East and altitude 14 Meters (45.93 Feet) above sea level (Figure 1). The dumpsite covers an area of about 10,000 $\mathrm{m}^{2}$ (1 hectare), and it is prone to flooding during the rainy season (between April and October). Ozoro community climate is characterized by two seasons: the wet season and the dry season. The wet season starts from around march and ends in October within the average rainfall of $1600 \mathrm{~mm}$ to $1800 \mathrm{~mm}$. while the dry seasons starts around November and ends in march [13]. Solid Wastes (plastic materials, food items, grass clippings, abandoned furniture, street sweepings, etc.) are brought from Ozoro metropolis and environs and dumped by the municipality waste collection contractor's trucks and indigenes of the community. The dumpsite is surrounded by residential and commercial building, including the State polytechnic and the local government council secretariat.

\section{Water Samples Collection}

Four (4) groundwater samples were collected from the study area. Out of the four water samples, one (1) was hand dug well water; while the other three (3) were borehole water. Then another groundwater was sampled from a location of about one kilometer from the dumpsite, with no history of waste disposal for the past ten years; which was taken as the reference point (Control). Description of the sample points were the water samples were taken is summarized in (Table 1). All the water samples were taken during at the end of the rainy season (November, 2020.). All the water sampled were poured into plastic containers (Figure 2), placed inside ice-box and taken immediately to the laboratory for laboratory analysis. 


\section{Civil Engineering Research Journal}

Table 1: Description of the sample points.

\begin{tabular}{|c|c|c|}
\hline Spatial point & Geographical coordinates & Remarks \\
\hline Point A & Lat. $5.550^{\circ} \mathrm{N}$; Long $6.245^{\circ} \mathrm{E}$ & $100 \mathrm{~m}$ from the front of the dumpsite (borehole) \\
\hline Point B & Lat. $5.555^{\circ} \mathrm{N}$; Long $6.244^{\circ} \mathrm{E}$ & $\begin{array}{c}\text { Back of the dumpsite, about } 100 \mathrm{~m} \text { downward away from the dumpsite. } \\
\text { (borehole) }\end{array}$ \\
\hline Point C & Lat. $5.554^{\circ} \mathrm{N}$; Long $6.250^{\circ} \mathrm{E}$ & $200 \mathrm{~m}$ away from the dumpsite, in the western direction. (local well) \\
\hline Point D & Lat. $5.555^{\circ} \mathrm{N}$; Long $6.243^{\circ} \mathrm{E}$ & 200 m downward away from the dumpsite. (borehole) \\
\hline Point E & Lat. $5.559^{\circ} \mathrm{N}$; Long $6.249^{\circ} \mathrm{E}$ & $1000 \mathrm{~m}$ (upland) north of the dumpsite (borehole) \\
\hline
\end{tabular}

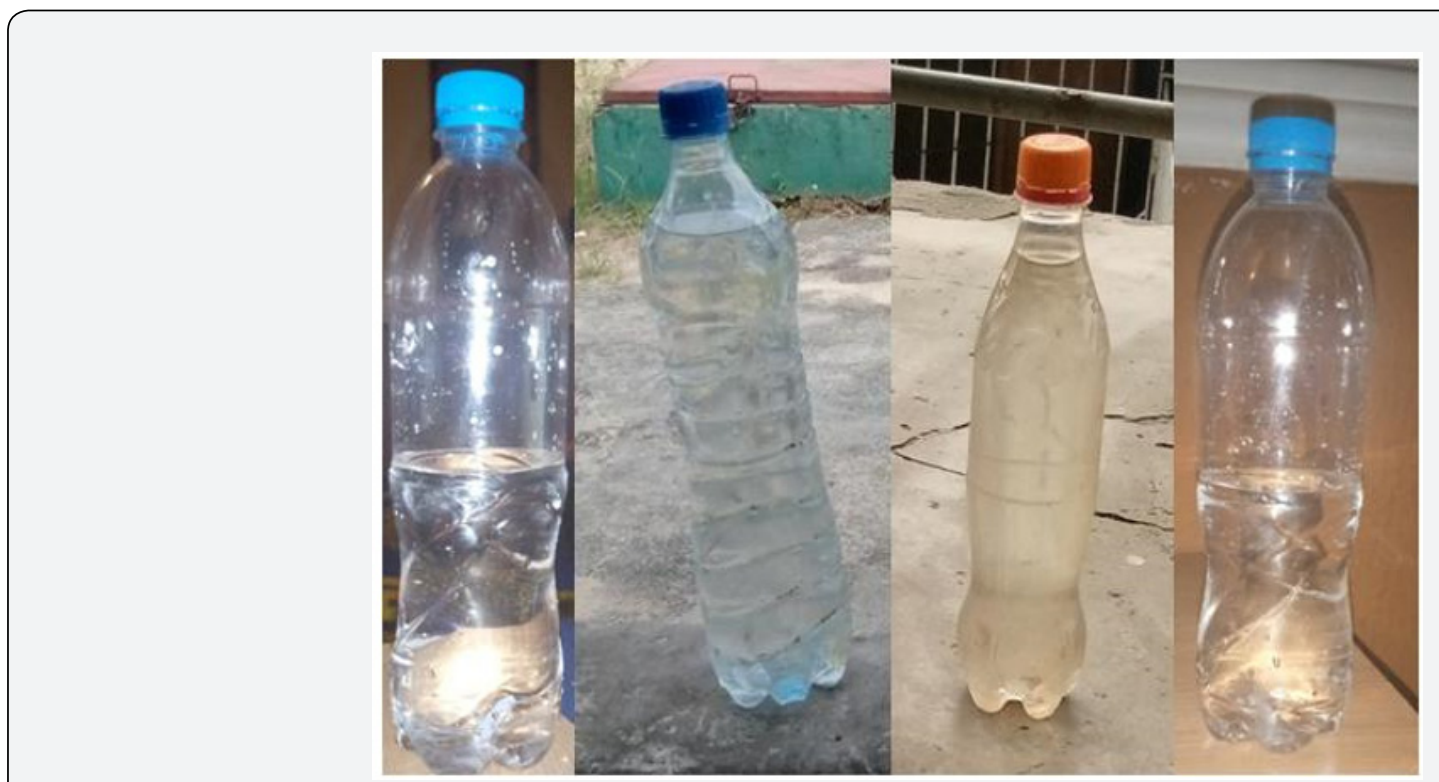

Figure 2: The sampled groundwater samples.

\section{Water Samples Laboratory Analysis}

\section{Heavy Metals Determination}

The water samples were digested according to ASTM International procedures. The lead, cadmium, nickel, zinc, copper and iron concentrations of the water samples were determined according to [14-18] standards, respectively; by using the atomicabsorption spectrophotometry (ABS), model TL-1800AA Series. All the laboratory tests were carried out at ambient laboratory temperature of $28 \pm 4^{\circ} \mathrm{C}$. All tests were done in triplicate and the average values recorded.

\section{Determination of the contamination rate}

In this present study, the two commonly accepted methods were used to determine the groundwater pollution; which are: contamination factor (CF) and pollution load index (PLI) [20]. The control (reference point) groundwater was taken at a point with no history solid or liquid population; to serve as the natural background metal concentration value. The PLI is used to evaluate the heavy metal contamination obtained as a contamination factor (CF) of each metal with respect to the natural background value $[21,22]$.

\section{Contamination Factor (Cf)}

This is the ratio of the heavy metal in the water sample to the concentration of the heavy metal in the baseline or background. It can be calculated using the expression provided by Hakanson [23], and shown in equation 1

$$
C f=\frac{\text { Conc. at the sampled point }}{\text { conc. at the reference point }}
$$

The scale of contamination factor is:

$C f<1=$ low contamination,

$1<C f<3=$ moderate contamination,

$3<C f<6=$ considerable contamination,

$C f>6=$ high contamination $[24]$

\section{Pollution Load Index (PLI)}

This represents the degree at which the heavy metals concentrations in the groundwater sampled exceed the 


\section{Civil Engineering Research Journal}

concentrations of the heavy metals at the reference point. It is calculated by using the expression given in Equation 2 [22,23].

$$
P L I=\sqrt[n]{C F 1 \times C F 2 \times C F 3 \times C F 4 \times \ldots \times C F n}
$$

Where:

$C F=$ contamination factor of each metal;

$n=$ total number of metals.

Pollution Load Index is classified as:

$P L I<1=$ unpolluted

\section{Results and Discussion}

\section{Groundwater Heavy Metals Concentration}

Table 2: The heavy metals concentration of the groundwater.

\begin{tabular}{|c|c|c|c|c|c|c|}
\hline Parameter & Iron (mg/L) & Cadmium (mg/L) & Copper (mg/L) & Zinc (mg/L) & Lead (mg/L) & Nickel (mg/L) \\
\hline Point A & $0.035 \pm 0.03$ & $0.003 \pm 0.001$ & $0.008 \pm 0.04$ & $0.388 \pm 0.03$ & $0.009 \pm 0.02$ & ND \\
\hline Point B & $0.058 \pm 0.04$ & $0.007 \pm 0.001$ & $0.018 \pm 0.02$ & $0.417 \pm 0.04$ & $0.072 \pm 0.01$ & $0.005 \pm 0.0$ \\
\hline Point C & $0.482 \pm 0.09$ & $0.004 \pm 0.001$ & $0.032 \pm 0.02$ & $0.501 \pm 0.05$ & $0.049 \pm 0.01$ & $0.001 \pm 0.0$ \\
\hline Point D & $0.021 \pm 0.03$ & ND & $0.015 \pm 0.03$ & $0.234 \pm 0.03$ & $0.004 \pm 0.01$ & ND \\
\hline Control & $0.005 \pm 0.02$ & ND & $0.006 \pm 0.01$ & $0.065 \pm 0.01$ & $0.002 \pm 0.001$ & ND \\
\hline WHO* & 0.03 & 0.005 & 0.5 & 1.5 & 0.015 & 0.02 \\
\hline
\end{tabular}

The average values of the heavy metals concentration in the groundwater samples collected from the various points, compared with WHO maximum permissible limits are presented in (Table 2). As revealed by the results, the $\mathrm{Cu}$ concentration of the groundwater samples varied across the vicinity of the dumpsite. The $\mathrm{Cu}$ concentrations range from $0.008 \mathrm{mg} / \mathrm{L}$ to 0.032 $\mathrm{mg} / \mathrm{L}$. According to the results, the copper concentration of the local well water had the highest $\mathrm{Cu}$ concentration $(0.032 \mathrm{mg} /)$; while the groundwater sampled from Location B had the lowest $\mathrm{Cu}$ concentration $(0.008 \mathrm{mg} / \mathrm{L})$. As shown by the results, all the groundwater sampled from the different location within the neighborhood of the dumpsite fall within the permissible limit approved by WHO for domestic water. With respect to the $\mathrm{Pb}$ concentration in the groundwater sampled, the results revealed that the $\mathrm{Pb}$ concentrations range from $0.004 \mathrm{mg} / \mathrm{L}$ to $0.072 \mathrm{mg} / \mathrm{L}$. The highest value of $\mathrm{Pb}(0.072 \mathrm{mg} / \mathrm{L})$ was recorded in Location B; which was higher than the WHO approved maximum permissible limit. This high $\mathrm{Pb}$ value can be attributed to its proximity to the dumpsite. Apart from Location B, the study results showed that the water sampled from the local well (location $\mathrm{C}$ ) contained $\mathrm{Pb}$ concentration $(0.049 \mathrm{mg} / \mathrm{L})$ which was also above the maximum permissible limit approved by WHO for domestic water. According to Khan et al. [22] industrial effluents, leachates from and car batteries, antifouling paints, etc. can increased the $\mathrm{Pb}$ concentration of the soil and water samples.

The Fe concentration of the groundwater ranged between $0.021 \mathrm{mg} / \mathrm{L}$ and $0.482 \mathrm{mg} / \mathrm{L}$. It was observed that the
$P L I=1$ baseline level of pollution

$1>P L I \leq 2$ moderately polluted

$2>P L I \leq 4$ highly polluted

$P L I>4$ very highly polluted [20]

\section{Data Analysis}

Data obtained from this study were subjected to descriptive statistical analysis, and the mean results were compared with those obtained by previous researcher [25] and the standard values recommended by the World Health Organization [26]. groundwater sampled from Location C (local well) had the highest Fe concentration of $0.482 \mathrm{mg} / \mathrm{L}$, which was above the permissible limit approved by WHO for domestic water. High Fe concentration recorded in the groundwater sampled from the local well, can be ascribed to the leaching/washing of the ferrous ions from the clay soil, which is the lining material of the well into the groundwater. Similarly, the results revealed that the groundwater sampled from Locations A and B, had Fe concentration higher than permissible limit approved by WHO. This may be attributed to the volume of the solid wastes leachates the groundwater received, and the proximity of the two locations to the dumpsite. Regarding the $\mathrm{Cd}$ concentration of the groundwater, the results revealed that the $\mathrm{Cd}$ concentration varied across the study area. It was observed that the Cd concentration ranged between $0.003 \mathrm{mg} / \mathrm{L}$ and $0.007 \mathrm{mg} / \mathrm{L}$. As shown by the results, groundwater at Location B contained Cd that was above the permissible limit stated by WHO. As seen in the results, Cd was not detected in the groundwater sampled from Location D and the reference point. While at Location A and C, the Cd concentration was within the WHO standard for domestic water; hence, it will not have any health concerns.

As revealed by the study results, the $\mathrm{Zn}$ concentration of the groundwater ranged from $0.234 \mathrm{mg} / \mathrm{L}$ to $0.501 \mathrm{mg} / \mathrm{L}$. The local well water recorded the highest $\mathrm{Zn}$ concentration of 0.501 $\mathrm{mg} / \mathrm{L}$; while water sampled from Locations A, B, and D had Zn concentrations of $0.388 \mathrm{mg} / \mathrm{L}, 0.417 \mathrm{mg} / \mathrm{L}$ and $0.234 \mathrm{mg} / \mathrm{L}$, respectively. The high $\mathrm{Zn}$ concentration recorded in the well water, despite its distance from the dumpsite, can be attributed to the 
seepage of other leachate into the well, the volume/concentration of surface water that flow into it, and the volume/concentration of contaminated precipitations it received, since the mouth of the local well was opened to the atmosphere. According to Glenn et al. [27], the high concentration of heavy metals in lagoon water, was due to the direct deposition of these heavy metals into the water bodies, through air pollution. Although the $\mathrm{Zn}$ concentration varied across the dumpsite vicinity, the results showed that the groundwater $\mathrm{Zn}$ concentrations, from all the sampled locations were below the permissible limits approved by WHO for domestic water. With respect to the $\mathrm{Ni}$ metal, the results disclosed that $\mathrm{Ni}$ was other detected in the groundwater sampled from Locations $\mathrm{B}$ and $\mathrm{C}$. As shown in the results, the Ni concentration at Location $\mathrm{B}$ was higher than the $\mathrm{Ni}$ concentration at Location $\mathrm{C}$. At location $\mathrm{B}$, groundwater had $\mathrm{Ni}$ concentration of $0.005 \mathrm{mg} / \mathrm{L}$; while at Location $\mathrm{C}$, the groundwater had Ni concentration of $0.001 \mathrm{mg} / \mathrm{L}$. Despite the locations of the spatial points within the dumpsite area, the Ni concentration was below the allowable limits approved by WHO standards. These results are in the same trend to previous researchers results. According to Naveen et al. [12] solid wastes have the ability of increasing the heavy metals concentrations in water bodies to a very dangerous level.

\section{Evaluation of the Groundwater Pollution Indices}

\section{Contamination factor}

The contamination factors of the heavy metals at the different locations are shown in (Figure 3). As presented in (Figure 3), the contamination factors of all the heavy metals investigated in this study varied across the study area. In general, Fe and Cd had the highest contamination factors across the study area; while copper and zinc had the lowest contamination factor across the study area. At location A, very high contamination was recorded for Fe and $\mathrm{Cd}$, while Ni recorded low contamination; likewise, $\mathrm{Zn}$ and $\mathrm{Pb}$ had considerable contamination. Then at location $\mathrm{B}$, it was observed that the $\mathrm{Fe}, \mathrm{Cd}, \mathrm{Ni}$ and $\mathrm{Pb}$ had very high contamination; while low contamination was recorded for $\mathrm{Cu}$. Similarly, at Location $\mathrm{C}$, the results showed that the $\mathrm{Fe}, \mathrm{Cd}, \mathrm{Ni}$ and $\mathrm{Pb}$ had very high contamination; while the $\mathrm{Cu}$ had low contamination at that Location. Lastly, at Location D, none of the heavy metals investigated had very high contamination, as the $\mathrm{Fe}$ and $\mathrm{Zn}$ contamination were of considerable degree; while $\mathrm{Cd}$ and $\mathrm{Ni}$ had low degree of contamination $C f<1$.

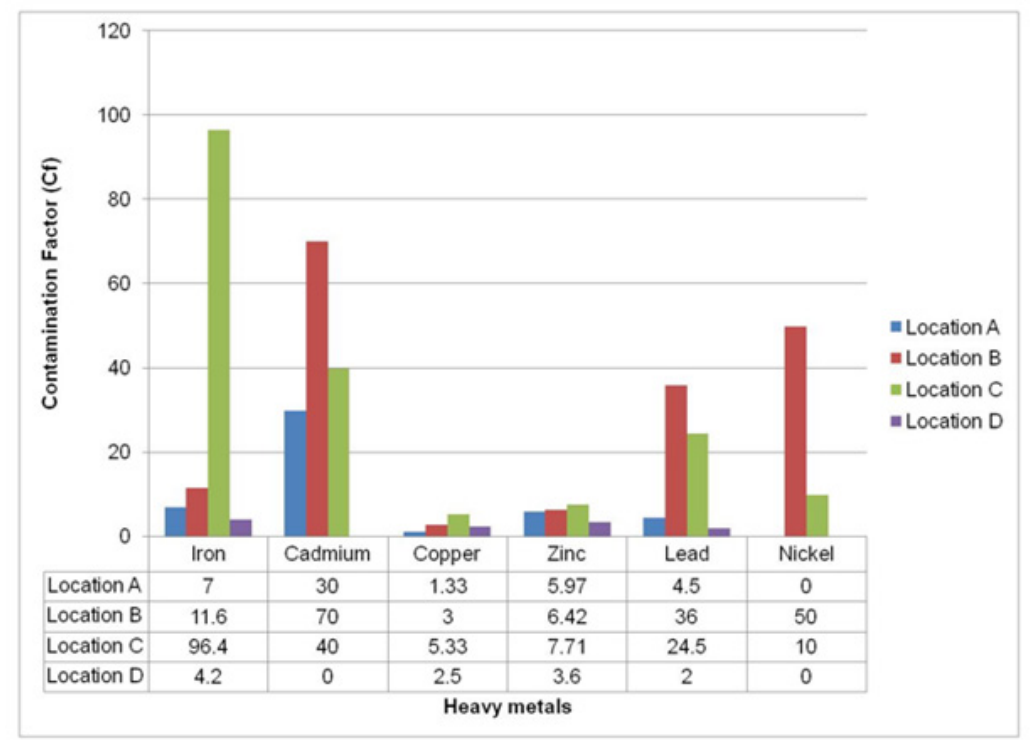

Figure 3: Contamination factors of the heavy metals in the groundwater.

\section{Pollution load index (PLI)}

The results of the pollution load index are given in (Figure 4). As shown in the results, the PLI values of all the heavy metals were greater than 1 , signifying that heavy metals pollution exists within the study area. As revealed by (Figure 4), the study area was highly polluted with $\mathrm{Fe}, \mathrm{Cd}, \mathrm{Zn}$ and $\mathrm{Ni}$; while the area was moderately pollution with $\mathrm{Cu}$. The high PLI values of Fe (13.47), Cd (43.8) and Ni (22.36), could be attributed to the type of solid wastes deposited in the dumpsite and the geotechnical properties of the underlying soil strata. Khan et al. [22] reported waste with high carbonate fraction and their concentrates, can lead to increase in the pollution rate of $\mathrm{Pb}$ and $\mathrm{Cd}$. Similar results were reported by Khan et al. [28], and the authors attributed the high PLI of the heavy metals, in the groundwater to the untreated leachates from wastewater discharge, fly ash ponds and industrial effluents from the Neyveli mines industrial complex [29]. Pollution Load Index helps to provide information about the total 


\section{Civil Engineering Research Journal}

level of heavy metal toxicity in the soil. Pollution Load Index helps to ascertain the full extent of contamination in the area, in order to alert the local authorities of the dangerous trend resulting from the dumpsite [30]. Since water is one of the basic necessity of life, the accumulation of these toxic heavy metals in human body, through the consumption of this populated groundwater, even at minute quality can cause neurological disorders, hormone imbalance, cardiovascular failure, kidney diseases, infertility, hair loss, endocrine disorders, respiratory and digestive problems, and cancer $[30,31,32]$.

Figure 4: Pollution load index of the heavy metals in the groundwater.

Correlation Relationship between the Heavy Metals in the Groundwater Samples

The results of the correlation analysis performed on the study results are presented in (Table 3). According to the Pearson statistical analysis, Fe showed a strong positive correlation with $\mathrm{Cu}$ and $\mathrm{Ni}$, while $\mathrm{Cd}$ showed a strong negative correlation with $\mathrm{Pb}$. Also, the results revealed that $\mathrm{Cu}$ had a strong positive correlation with Ni. According to Patil and Patil [33], correlation is the mutual relationship between two variables [33]. The strong correlation between $\mathrm{Fe}, \mathrm{Cu}$ and $\mathrm{Ni}$; and $\mathrm{Cu}$ and $\mathrm{Ni}$ indicates that the contamination likely to originated from the same contaminant $[34,35]$. These results had revealed that the dumpsite had negative impact on the environment, and the government environmental monitoring agencies should take appropriate actions to remediate the environment, to prevent the outbreak of water - borne diseases.

Table 3: Correlation matrix for the heavy metals in groundwater samples.

\begin{tabular}{|c|c|c|c|c|c|c|}
\hline & Iron & Cadmium & Copper & Zinc & Lead & \\
\hline Iron & 1 & & & & \\
\hline Cadmium & 0.2343 & 1 & & & \\
\hline Copper & 0.9596 & 0.4417 & 0.5655 & 0.842 & 1 & \\
\hline Zinc & 0.7637 & -0.9324 & -0.231 & -0.4143 & 1 & \\
\hline Lead & 0.0281 & 0.1243 & 0.9154 & 0.7471 & 0.1441 & 1 \\
\hline Nickel & 0.9889 & & & & \\
\hline
\end{tabular}

\section{Conclusion}

This study was carried out to evaluate the effect of solid waste leachate on the groundwater quality. Groundwater samples were collected from four different spatial locations, within the vicinity of an active dumpsite. Some heavy metals concentrations of the groundwater sampled were determined according to ASTM International methods; while the groundwater quality was determined by using the Pollution load index. Results obtained from the laboratory analyses revealed that, the leachates from 


\section{Civil Engineering Research Journal}

the solid wastes of the dumpsite had significant effect on the groundwater quality. This is because the concentrations of the six heavy metals tested for in the groundwater sampled, were higher than the concentrations of the heavy metals at the control point. In terms of the pollution load, the PLI results showed that the study area was highly polluted with $\mathrm{Fe}, \mathrm{Cd}, \mathrm{Zn}$ and $\mathrm{Ni}$; while the area was moderately pollution with $\mathrm{Cu}$. The high PLI values portrayed that the leachates from the solid wastes has effect on the groundwater quality of the area. These results had revealed that the dumpsite had negative impact on the environment, and the government environmental monitoring agencies should take appropriate actions to remediate the environment, to prevent the outbreak of water - borne diseases.

\section{References}

1. Adebo BA, Adetoyinbo AA (2009) Assessment of groundwater quality in unconsolidated sedimentary coastal aquifer in Lagos State, Nigeria. Scientific Research and Essay 4(4): 314-319.

2. Wang WX, Rainbow PS (2008) Comparative approaches to understand metal bioaccumulation in aquatic animals. Comparative Biochemistry and Physiology-C Toxicology and Pharmacology 148(4): 315-323.

3. (2018) Agency for Toxic Substances and Disease Registry - ATSDR Toxicological profile for copper. US Department of Health and Human Service, Public Health Service.

4. Akpomrere OR, Uguru H (2020) Potential ecological risk of swamps sediments in illegal refineries sites: A Case Study of Isoko South, Delta State, Nigeria. Journal of Engineering Research and Reports 16(2): 1-9.

5. Mohammad U, Hamidi A, Mohd SY (2010) Variability of Parameters involved in leachate pollution index and determination of LPI from four landfills in Malaysia. International Journal of Chemical Engineering.

6. Egbai JC, Adaikpoh, EO, Aigbogun CO (2013) Water quality assessment of groundwater in Okwuagbe Community of Delta State Nigeria. Technical Journal of Engineering and Applied Sciences (TJEAS) 3(19): 2347-2356.

7. Ofomola MO Umayah OS, Akpoyibo O (2017) Contamination Assessment of dumpsites in Ughelli, Nigeria using the Leachate Pollution Index method. J Appl Sci Environ Manage 21(1): 77-84.

8. Al-Khaldi S (2006) Assessment of groundwater contamination vulnerability in the vicinity of Abqaiq landfill- A GIS Approach, King Fahd University of Petroleum and Minerals, Saudi Arabia.

9. Akpomrere OR, Uguru H (2020) Copper concentration and distribution in the ground water of Delta State Polytechnic, Ozoro, Nigeria. Asian Journal of Geographical Research 3(3): 1-8.

10. Rafizul IM, Alamgir M, Kraft E, Haedrich G (2011) Bio-treatment of leachate generated from municipal solid waste in sanitary landfill lysimeter. $2^{\text {nd }}$ International conference on solid waste management in developing Asian countries, KUEST, Bangladesh.191-193.

11. Olagunju O, Badmus, O, Ogunlana, F, Babalola M (2018) Environmental Impact Assessment of Waste Dumpsite using Integrated Geochemical and Physico-Chemical Approach: A Case Study of Ilokun Waste Dumpsite, Ado - Ekiti, Southern Nigeria. Civil Engineering Research Journal 4(2): 1-13.

12. Naveen BP, Sumalatha J, Malik RK (2018) A study on contamination of ground and surface water bodies by leachate leakage from a landfill in Bangalore, India. International Journal of Geo-Engineering p: 9-27.

13. Eboibi O, Akpokodje OI Uguru H (2018) Growth performance of five bean (Phaseolus spp) varieties as influenced by organic amendment. Journal of Applied Sciences \& Environmental Management 22(5): 759763.

14. (2015) ASTM D3559-15. Standard Test Methods for Lead in Water, ASTM International, West Conshohocken, PA.

15. (2017) ASTM D3557-17. Standard Test Methods for Cadmium in Water, ASTM International, West Conshohocken, PA.

16. (2014) ASTM D1886-14. Standard Test Methods for Nickel in Water, ASTM International, West Conshohocken, PA.

17. (2017) ASTM D1688-17. Standard Test Methods for Copper in Water, ASTM International, West Conshohocken, PA.

18. (2015) ASTM D1068-15. Standard Test Methods for Iron in Water, ASTM International, West Conshohocken, PA

19. (2017) ASTM D1691-17. Standard Test Methods for Zinc in Water, ASTM International, West Conshohocken, PA.

20. Thomilson DC, Wilson DJ, Harris CR, Jeffrey DW (1980) Problem in heavy metals in estuaries and the formation of pollution index. Helgol Mar Res 33: 566-575.

21. Adamo P, Arienzo M, Imperato M, Naimo D, Nardi G (2005) Distribution and partition of heavy metals in surface and sub-surface sediments of Naples city port. Chemosphere 61(6): 800-809.

22. Khan MZ, Hasan MR, Khan M, Aktar S, Fatema K (2017) Distribution of Heavy Metals in Surface Sediments of the Bay of Bengal Coast. Journal of toxicology 9235764 .

23. Hakanson L (1980) Ecological Risk Index for Aquatic Pollution Control. A Sedimentological Approach, Water Research 14: 975-1001.

24. Edet AE, Offiong OE (2002) Evaluation of water quality indices for heavy metal contamination monitoring. A study case from AkpabuyoOdukpani area, Lower cross River Basin (southeastern Nigeria). Geo Journal 57: 295-304.

25. Longe EO, Balogun MR (2010) Groundwater quality assessment near a municipal landfill, Lagos, Nigeria. Research Journal of Applied Sciences Engineering and Technology 2(1): 39-44.

26. (2004) World Health Organization - WHO (2004) Cost and benefits of water and sanitation improvements.

27. Glenn SS, Sia S, Kristine JM, Tessa PA, Elena R (2009) Assessing heavy metals in the waters, fish and macroinvertebrates in Manila bay, Philippines. Journal of Applied Sciences in Environment Sanitation 4(3): 187-195.

28. Khan R, Israili SH, Mohan A (2005) Heavy metal pollution assessment in surface water bodies and its suitability for irrigation around the Neyveli lignite mines and associated industrial complex, Tamil Nadu, India. Mine Water and Environment 24: 155-161.

29. Brraich OS, Jangu S (2015) Evaluation of water quality pollution indices for heavy metal contamination monitoring in the water of Harike Wetland (Ramsar Site), India. International Journal of Scientific and Research Publications 5(2): 1- 6.

30. Shirani Md Afzali KN, Jahan S, Strezov V, Soleimani-Sardo M (2020) Pollution and contamination assessment of heavy metals in the sediments of Jazmurian playa in southeast Iran. Scientific Reports 10: 4775 .

31. Shirani M, Akbari A, Hassani, M (2015) Adsorption of cadmium(ii) and copper(ii) from soil and water samples onto a magnetic organozeolite modifed with 2-(3,4-dihydroxyphenyl)-1,3-dithiane using an artifcial neural network and analysed by fame atomic absorption spectrometry. Anal Method 7: 6012-6020. 


\section{Civil Engineering Research Journal}

32. Tepanosyan G, Maghakyan N, Sahakyan L, Saghatelyan A (2017) Heavy metals pollution levels and children health risk assessment of Yerevan kindergartens soils. Ecotoxicology and Environmental Safety 142: 257-265.

33. Patil VT, Patil P R (2011). Groundwater quality of open wells and tube wells around Amalner town of Jalgaon, district, Maharashtra, India. Electronic Journal of Chemistry 8(1): 53-78.

34. (2020) Google mapdata. Nigeria Map.

35. Hauser BA (2002) Drinking Water Chemistry, a Laboratory Manual. USA: CRC Press.

Your next submission with Juniper Publishers will reach you the below assets

- Quality Editorial service

- Swift Peer Review

- Reprints availability

- E-prints Service

- Manuscript Podcast for convenient understanding

- Global attainment for your research

- Manuscript accessibility in different formats

(Pdf, E-pub, Full Text, Audio)

- Unceasing customer service

Track the below URL for one-step submission https://juniperpublishers.com/online-submission.php 